\title{
RESPON KELOMPOK WANITA TANI SIDOMAJU TERHADAP METODE MARINASI PRA PENGOLAHAN DAGING AYAM BROILER DI DESA BANJARSARI KECAMATAN WINDUSARI
}

\author{
Nia Astuti ${ }^{1)}$, Nur Prabewi ${ }^{2)}$, Suharti $^{2)}$ \\ ${ }^{1)}$ Mahasiswa STPP Magelang \\ 2) Staf Pengajar STPP Magelang \\ email: bewinurprabewi@gmail.com
}

\begin{abstract}
ABSTRAK
Karya Ilmiah Penugasan Akhir (KIPA) dilaksanakan dari tanggal 05 Maret sampai dengan 30 April 2018 di Kelompok Wanita Tani (KWT) Sidomaju Desa Banjarsari Kecamatan Windusari Kabupaten Magelang Jawa Tengah. Tujuan yang ingin dicapai adalah untuk mengetahui tingkat respon kelompok wanita tani terhadap metode marinasi pra pengolahan daging ayam, dan untuk mengetahui tingkat Efektivitas Penyuluhan (EP) tentang metode marinasi pra pengolahan daging ayam, serta pembuktian apakah ada perbedaan rata-rata antara nilai pra test (sebelum) dan post test (sesudah) dilakukan penyuluhan.

Penentuan sampel menggunakan metode sensus dari kelompok wanita tani "Sidomaju" sebanyak 34 orang. Variabel yang diamati yaitu pengetahuan, sikap dan keterampilan dari hasil pra test (sebelum) dan post test (sesudah) dilakukannya penyuluhan. Untuk mengetahui respon kelompok wanita tani "Sidomaju" diukur dengan menggunakan skala likert. Sedangkan metode analisis data menggunakan metode deskriptif komparatif.

Hasil pengkajian menunjukkan peningkatan pada respon dari aspek pengetahuan, aspek sikap dan aspek keterampilan diperoleh nilai pra test 37,6 (respon rendah), sedangkan hasil rata-rata nilai post test menjadi 57,2 (respon tinggi) atau dapat dikatakan dari respon rendah menjadi respon tinggi, dengan nilai EP sebesar 71,5\% termasuk dalam kategori efektif. Sedangkan hasil analisis uji paired t-test terdapat perbedaan yang nyata/signifikan antara respon petani pada saat pra test (sebelum) dan post test (setelah) dilakukan penyuluhan.

Kesimpulan adalah tingkat respon kelompok wanita tani terhadap metode marinasi pra pengolahan daging ayam memperoleh nilai 57,2 termasuk kategori tingkat respon tinggi, dan tingkat Efektivitas Penyuluhan (EP) tentang metode marinasi pra pengolahan daging ayam sebesar $71,5 \%$ termasuk dalam kategori efektif, serta pembuktian perbedaan rata-rata antara nilai pra test (sebelum) dan post test (sesudah) dilakukan penyuluhan menggunakan analisis uji paired $t$-test terdapat perbedaan yang nyata/signifikan.
\end{abstract}

Kata kunci : Respon, Wanita Tani ,Metode Marinasi, Pra Pengolahan, Daging Ayam.

\section{SIDOMAJU FARMING GROUP RESPONSE ON THE METHOD OF PRE MARCH MEAT PROCESSING BROILER IN BANJARSARI VILLAGE KECAMATAN WINDUSARI}

\section{ABSTRACT}

The Final Assignment Scientific Work (KIPA) was held from March 5 to April 30, 2018 in the Women Farmers Group (KWT) Sidomaju, Banjarsari Village, Windusari 
District, Magelang District, Central Java. The aim to be achieved is to determine the level of response from farmer women groups to the pre-marination method of chicken meat processing, and to determine the level of Extension Effectiveness (EP) on the premarination method of chicken meat processing, as well as proving whether there are differences in the average value between the pre-test values (before) and post test (after) counseling. Determination of sample using census method from farmer woman group "Sidomaju" as many as 34 people. The variables observed were knowledge, attitudes and skills from the results of pre-test (before) and post-test (after) conducted counseling. To find out the response of women farmer groups "Sidomaju" was measured using a Likert scale. While the method of data analysis uses descriptive comparative methods. The results of the study showed an increase in the response from aspects of knowledge, attitude aspects and skills aspects obtained pre-test value 37.6 (low response), while the average score of the post test score was 57.2 (high response) or it could be said from the low response to high response, with an EP value of $71.5 \%$ included in the effective category. While the results of the paired t-test analysis showed significant / significant differences between the responses of farmers when the pre-test (before) and post-test (after) were conducted counseling. Conclusion is the level of response of farmer women groups to the method of pre-processing marinated chicken meat obtained a value of 57.2 including the category of high response rates, and the level of Extension Effectiveness (EP) about the method of pre-processing marinated chicken meat $71.5 \%$ included in the effective category, and proving the difference in average between the pre-test (before) and post-test (after) values carried out counseling using the paired t-test analysis there are significant I significant differences. Keywords: Response, Farm Woman, Marination Method, PreProcessing, Chicken Meat.

\section{PENDAHULUAN}

\section{A. Latar Belakang}

Daging ayam merupakan bahan makanan asal hewani yang digemari oleh seluruh lapisan masyarakat dan merupakan produk pangan asal unggas yang sering mengalami penurunan kualitas baik fisik maupun kimianya.Untuk meningkatkan kualitas daging ayam broiler sebelum pengolahan diperlukan perlakuan dengan metode marinasi.

Marinasi adalah proses perendaman daging di dalam bahan marinade, sebelum diolah lebih lanjut. Marinade merupakan cairan berbumbu yang berfungsi sebagai bahan perendam daging, biasanya digunakan untuk memperpanjang masa simpan daging, mempertahankan kualitas daging dan meningkatkan keamanan kandungan gizi daging (Nurohim dkk., 2013).
Desa Banjarsari merupakan wilayah yang ada di Kecamatan Windusari Kabupaten Magelang yang memiliki populasi komoditas ternak ayam broiler yang cukup banyak, kelompok wanita tani di desa tersebut banyak mengolah hasil dari ternak ayam broiler menjadi berbagai macam olahan masakan.

Berdasarkan latar belakang tersebut maka dilakukan pengkajian tentang "Respon Kelompok Wanita Tani Sidomaju Terhadap Metode Marinasi Pra Pengolahan Daging Ayam Broiler Di Desa Banjarsari Kecamatan Windusari”.

\section{B. Perumusan Masalah}

Berdasarkan hasil identifikasi wilayah dapat dirumuskan masalahsebagai berikut :

1. Belum diketahuinya respon kelompok wanita tani Sidomaju terhadap metode marinasi pra pengolahan daging ayam. 
2. Belum adanya penyuluhan tentang metode marinasi pra pengolahan daging ayam di kelompok wanita tani "Sidomaju".

\section{Tujuan}

Berdasarkan perumusan masalah, tujuan penelitian ini antara lain yaitu :

1. Mengetahuitingkatresponkelompok wanita tani Sidomaju terhadap metode marinasi pra pengolahan daging ayam.

2. Mengetahui tingkat Efektivitas Penyuluhan (EP) tentang metode marinasi pra pengolahan daging ayam.

3. Untuk mengetahui apakah ada perbedaan rata-rata antara nilai pra test (sebelum) dan post test (sesudah) dilakukan penyuluhan.

\section{Hipotesis}

Hipotesa dalam kajian ini antara lain yaitu :

1. Diduga respon kelompok wanita tani Sidomaju terhadap adanya penyuluhan tentang metode marinasi pra pengolahan daging ayam broilertermasuk kategori tinggi.

2. Diduga Efektivitas Penyuluhan (EP) tentang metode marinasi pra pengolahan daging ayam broiler termasuk dalam kategori efektif.

3. Diduga terdapat perbedaan yang nyata antara nilai pra test dan post test setelah dilakukan penyuluhan.

\section{METODOLOGI}

A. Waktu dan Tempat

Pelaksanaan Karya Ilmiah Penugasan Akhir (KIPA) dilaksanakan mulai tanggal 05 Maret sampai dengan tanggal 30 April 2018, berlokasi di Kelompok Wanita Tani "Sidomaju", Desa Banjarsari Kecamatan
Windusari Kabupaten Magelang Jawa Tengah.

\section{B. Bahan dan Alat}

\section{Bahan}

Bahan-bahan yang digunakan adalah kertas HVS 80 gram, sedangkan bahan untuk demonstrasi cara dalam penyuluhan antara lain adalah : a) Daging ayam $1 \mathrm{~kg}, \mathrm{~b}$ ) Jahe 1 ruas, c) Lengkuas 3 ruas, d) Jintan 20-40 biji, e) Bawang putih 10 siung, g) Jeruk nipis $1 / 2$ biji, h) Serai 2 batang, g) Air $300 \mathrm{ml}$.

\section{Alat}

Alat bantu yang digunakan dalam pelaksanaan penyuluhan antara lain adalah : a) Panduan wawancara, b) Alat tulis (pensil 2B, penghapus, buku tulis), c) Kamera (Lenovo), d) Leaflet, e) Laptop, f) LCD. Sedangkan alat bantu untuk demonstrasi cara antara lain adalah : a) Timbangan digital, b) Blender/ulekan, c) Pisau, d) Talenan, dan e) Ember.

\section{Rancangan atau Desain}

Rancangan pengkajian yang dilaksanakan adalah menggunakan rancangan sebelum dan sesudah, dengan satu kelompok atau one group pra test-post test, Suryabrata (2005) dalam Susanto (2013). Rancangan ini dapat digambarkan $\left(\mathrm{O}_{1}-\mathrm{T}-\mathrm{O}_{2}\right)$ dengan penjelasan sebagai berikut :

$\mathrm{O}_{1}$ : Pretest, untuk mengukur pengetahuan, sikap dan keterampilan responden sebelum mengikuti penyuluhan.

$\mathrm{T}$ : Treatment, perlakuan/kegiatan penyuluhan yang ditujukan kepada responden yang sama

$\mathrm{O}_{2}$ : Posttest, untuk mengetahui tingkat pengetahuan, sikap dan 
keterampilan responden sesudah mengikuti penyuluhan

Respon dilihat dengan membandingkan hasil dari pra test dan post test dari aspek pengetahuan, sikap dan keterampilan. Hasil tersebut diukur menggunakan skala likert yaitu : dengan pengkategorian untuk tiap-tiap aspek diberikan skor, dimana daftar pertanyaan yang ada di panduan wawancara didasarkan pada variabel yang diamati.

\section{Populasi dan Sampel}

\section{Populasi}

Jumlah populasi yang ada di kelompok wanita tani Sidomaju Desa Banjarsari Kecamatan Windusari berjumlah 34 orang yang merupakan anggota kelompok wanita tani Sidomaju.Populasi adalah sekelompok objek atau individu atau peristiwa yang menjadi perhatian peneliti, yang dikenai generalisasi penelitian (Roman, 2013 dalam Widiartha, 2017)

\section{Sampel}

Metode pengambilan sampel yang dilakukan melaui sensus yaitu responden diambil secara keseluruhan dari seluruh anggota Kelompok Wanita Tani (KWT) Sidomaju.Metode sensus adalah metode yang keseluruhan anggota populasi dijadikan responden (Sugiyono, 1994 dalam Sasetyowati, 2013).Sampel yang diperoleh yaitu 34 orang sebagai responden.Hal ini sesuai dengan pendapat Arikunto (2006) dalam Faqih (2015), bahwa apabila jumlah populasi kurang dari 100 orang, maka seluruhnya dijadikan sampel.

\section{E. Data dan Sumber Data}

\section{Data Primer}

Data primer didapat dari lokasi pelaksanaan pengkajian dengan observasi dan wawancara langsung kepada responden dengan menggunakan alat bantu panduan wawancara. Pertanyaan mengacu pada panduan wawancara yang berisi pertanyaan yang dibutuhkan untuk mendapatkan data yang diperlukan seperti nama, umur, jenis kelamin, tingkat pendidikan, jumlah keluarga, serta data pengetahuan, sikap dan keterampilan. Pengumpulan data yang dilaksanakan dengan cara :

a. Wawancara menggunakan panduan wawancara yang disampaikan langsung pada responden melalui kunjungan anjangsana kelokasi usaha ataupun rumah responden untuk menjawab pertanyaan-pertanyaan dalam panduan wawancara yang telah disiapkan.

b. Observasi yakni pengamatan langsung ke rumah responden untuk memperoleh data yang lebih lengkap guna membantu dalam memberikan penjelasan yang lebih mendasar dan mendalam terhadap hasil kegiatan.

\section{Data Sekunder}

Data sekunder diperoleh dengan cara pendataan dan dokumentasi dari sumber yang berkaitan terhadap data yang diperlukan seperti kantor Balai Desa Banjarsari dan Balai Penyuluhan Kecamatan Windusari. Data sekunder digunakaan sebagai data pendukung dalam penelitian.

\section{F. Analisis Data}

\section{Analisis Deskriptif}

Analisis deskriptif adalah metode yang digunakan untuk memperoleh gambaran (deskripsi) terhadap variabelvariabel yang diteliti dan memberikan interpretasinya sesuai dengan tujuan kajian yang telah ditetapkan yaitu membandingkan tingkat respon 
(pengetahuan, sikap, keterampilan) sebelum dan sesudah penyuluhan. Analisa data yang digunakan untuk mengukur respon kelompok wanita tani adalah dengan menggunakan analisa deskriptif komparatif yaitu membandingkan hasil dari pra test dan post test dari aspek pengetahuan, sikap dan keterampilan. Hasil tersebut diukur menggunakan skala likert.

\section{Analisis Statistik}

Analisis statistik yang digunakan yaitu analisis uji-t (paired t-test) atau uji beda yang digunakan untuk membandingkan selisih dua rata-rata dari dua sampel berpasangan dengan asumsi data berdistribusi normal (S. Uyanto, 2006 dalam Aripin, 2008). Sampel yang dimaksud adalah sampel yang sama namun mengalami proses pengukuran maupun perlakuan yang berbeda. Analisis ini digunakan untuk mengetahui perbedaan antara hasil dari nilai pra test (sebelum) dan post test (sesudah) dilakukan penyuluhan. Analisis ini digunakan untuk mengukur perbandingan rata-rata (mean) menyangkut data yang diperoleh dengan cara ditabulasikan. Selisih dari kenaikan post test dan pra test kemudian dijadikan perbandingan yang dapat menyatakan bahwa respon petani berbeda nyata atau tidak berbeda nyata. Namun sebelum dianalisis dengan uji paired t-test, data terlebih dahulu dilakukan uji normalitas. a. Uji Normalitas Data

Pada dasarnya uji normalitas dilakukan untuk mengetahui apakah data yang diperoleh berasal dari populasi yang berdistribusi normal atau tidak. One sample Kolmogorov Smirnov Test adalah salah satu uji normalitas untuk data yang berasal dari satu sampel (Herawati, L, 2016). Menurut Anastasya (2013), yang menyatakan bahwa asumsi uji normalitas menggunakan One Sample Kolmogorov Smirnovadalah : 1) Sig $>0,05$ berarti data terdistribusi dengan normal, 2) Sig $<0,05$ berarti data tidak terdistribusi dengan normal. Bila data berdistribusi normal, maka dilakukan analisis yaitu dengan uji beda untuk menguji hipotesis komparatif dan nilai signifikasi dengan rumus Paired t-test.

\section{HASIL DAN PEMBAHASAN}

\section{A. Hasil Penyuluhan}

Hasil kegiatan penyuluhan di Kelompok Wanita Tani Sidomaju Desa Banjarsari Kecamatan Windusari Kabupaten Magelang dengan melakukan analisis terhadap variabel aspek pengetahuan, sikap dan keterampilan.Selanjutnya dari variabel tersebut dapat diketahui tingkat respon anggota kelompok wanita tani dan juga efektivitas penyuluhan yang dilakukan. Hasil kegiatan penyuluhan di Kelompok Wanita Tani Sidomaju dapat dilihat pada tabel dibawah ini :

Tabel 1. Hasil Kegiatan Penyuluhan di Kelompok Wanita Tani Sidomaju

\begin{tabular}{lrcrcr}
\hline \multirow{2}{*}{ Variabel } & \multicolumn{2}{c}{ Pra Test } & \multicolumn{2}{c}{ Post Test } & \multirow{2}{*}{ Selisih } \\
\cline { 2 - 5 } & Nilai & Kategori & Nilai & Kategori & \\
\hline Pengetahuan & 13,0 & Kurang Tahu & 22.4 & Cukup Tahu & 9.4 \\
Sikap & 15,5 & Ragu & 20.3 & Setuju & 4.8 \\
Keterampilan & 9,1 & Kurang Terampil & 14.5 & Terampil & 5.4 \\
Respon & 37,6 & Rendah & 57.2 & Tinggi & 19.6 \\
\hline Sunn
\end{tabular}

Sumber: Data PrimerTerolah Tahun 2018 


\section{Aspek Pengetahuan}

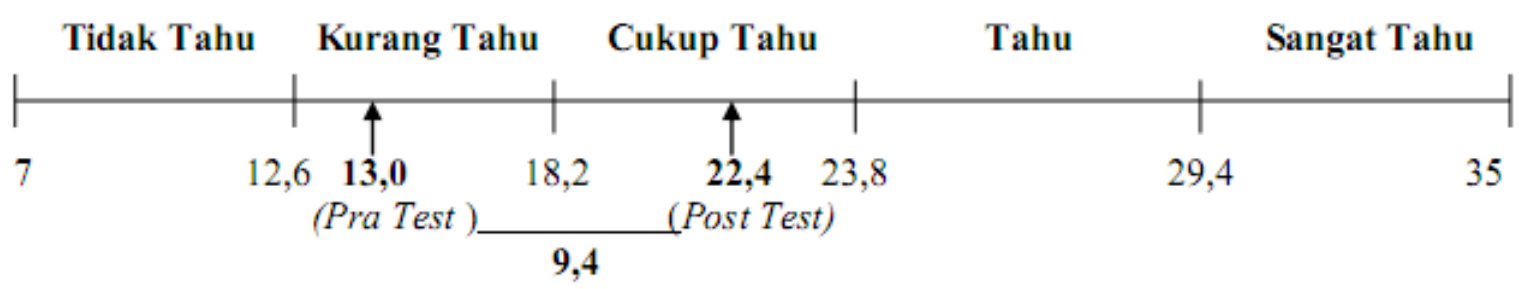

Berdasarkan rekapitulasi pra dan post test pada aspek pengetahuan diperoleh hasil sebelum dilakukan penyuluhan (pra test) adalah 13,0 (kurang tahu) dan hasil setelah penyuluhan (post test) adalah 22,4 (cukup tahu), dengan demikian terjadi peningkatan sebesar 9,4 atau dari kurang tahu menjadi cukup tahu. Peningkatan aspek pengetahuan tinggi menunjukkan suatu perubahan nilai yang baik, dapat diketahui melalui tingkat pemahaman dan penguasaan terhadap materi teknologi yang baru diterima dari sebelum dan sesudah dilakukan penyuluhan.

\section{Aspek Sikap}

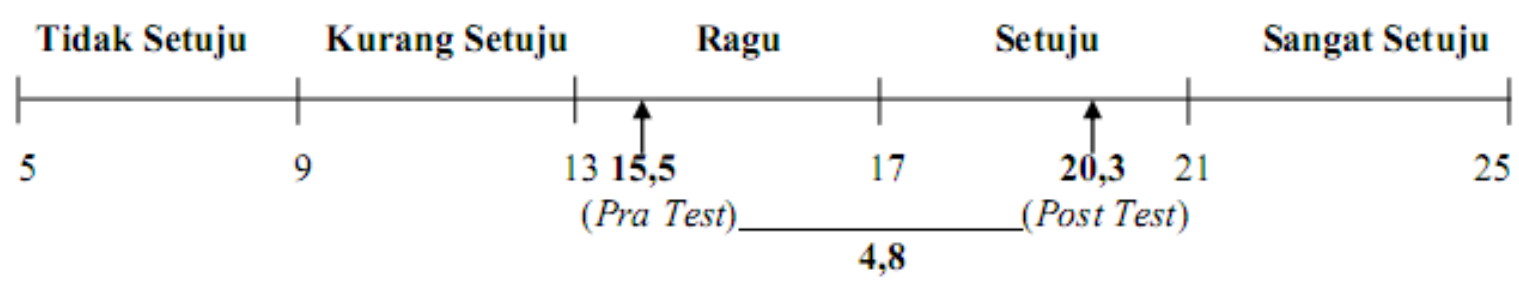

Berdasarkan rekapitulasi pra dan post test pada aspek sikap diperoleh hasil sebelum dilakukan penyuluhan (pra test) adalah 15,5 (ragu-ragu) dan hasil setelah penyuluhan (post test) adalah 20,3 (mau), dengan demikian terjadi peningkatan sebesar 4,8 atau dari ragu-ragu menjadi mau.Sesuai dengan pendapat Fatmawati (2004) dalam Iswandari (2006), perubahan sikap mencakup perubahan dalam pemikiran dan perasaan untuk mengadakan suatu balasan terhadap suatu objek, gagasan atau situasi dalam bentuk reaksi.Sikap dapat digunakan sebagai parameter respon karena sikap ini merupakan salah satu bentuk respon petani terhadap rangsangan yang ada.Sikap terhadap inovasi baru dapat berupa sikap positif (mendukung atau menerima) inovasi tersebut atau sikap yang negatif menolak inovasi tersebut, hal ini karena adanya reaksi dari luar diri seseorang.

\section{Aspek Keterampilan}

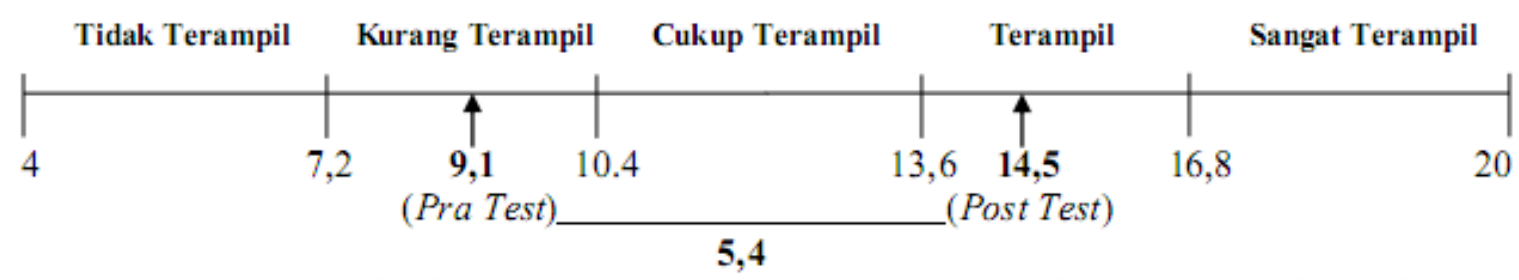


Berdasarkan rekapitulasi pra dan post test pada aspek keterampilan diperoleh hasil sebelum dilakukan penyuluhan (pra test) adalah 9,1 (kurang terampil) dan hasil setelah penyuluhan (post test) adalah 14,5 (terampil), dengan demikian terjadi peningkatan sebesar 5,4 atau dari kurang terampil menjadi terampil. Hal ini disebabkan oleh adanya dampak dari kegiatan penyuluhan yang telah diberikan khususnya demonstrasi cara, sehingga responden dapat melihat dan mempraktikkan secara langsung. Hal ini sesuai dengan pendapat Mardikanto (1999), bahwa dengan petani melihat sendiri mereka akan lebih percaya dengan penyuluhan yang kita berikan dan dengan kepercayaan tersebut mereka akan terdorong untuk melakukan tindakan terhadap inovasi baru yang diterima.

\section{Respon}

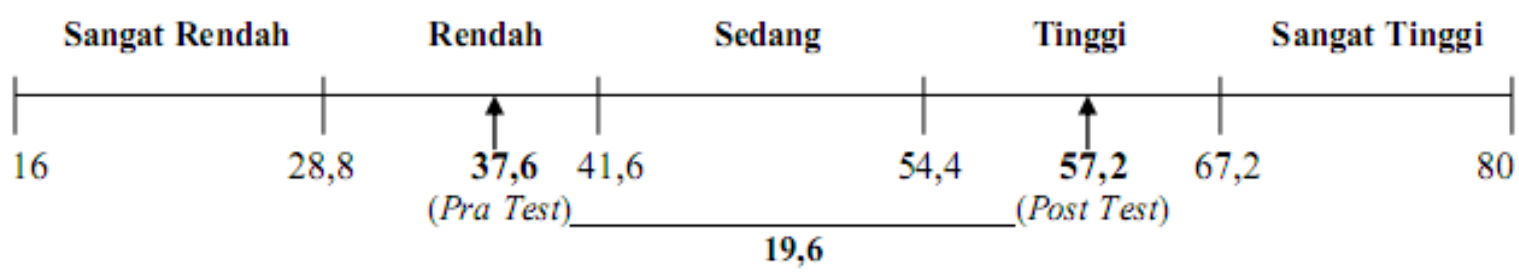

Berdasarkan hasil analisis secara keseluruhan dari ketiga aspek pengetahuan, sikap dan keterampilan, respon anggota kelompok wanita tani terhadap kegiatan penyuluhan diperoleh hasil respon sebelum penyuluhan (pra test) adalah 37,6 (respon rendah) dan setelah dilakukan penyuluhan (post test) respon menjadi 57,2 (respon tinggi), atau dari respon rendah menjadi respon tinggi dan terjadi peningkatan sebesar 19,6.

\section{Efektivitas Penyuluhan}

Menurut Ginting (1993) dalam Susanto (2013), tingkat efektivitas dikategorikan sesuai kriteria dengan skor 0$20 \%=$ Tidak efektif, skor $21-40 \%=$ Kurang efektif, skor $41-60 \%=$ Cukup efektif, skor $61-80 \%=$ Efektif, dan skor 81$100 \%=$ Sangat efektif.

\section{Hasil perhitungan Efektivitas}

Penyuluhan (EP) dan Efektivitas Perubahan Perilaku (EPP) dari seluruh aspek (pengetahuan, sikap, keterampilan) yang telah dilakuakn yaitu :

$\mathrm{EP} \quad=71.5 /$ Efektif
$\mathrm{EPP} \quad=46.2 /$ Cukup efektif Perhitungan EP (Efektivitas Penyuluhan) dan EPP (Efektivitas Perubahan Perilaku) terdapat pada Lampiran 11. Dari nilai yang didapatkan menunjukkan bahwa hasil Efektivitas Penyuluhan (EP) sebesar 71,5\% dalam kategori efektif, berarti bahwa kegiatan penyuluhan dengan metode ceramah, diskusi dan demonstrasi cara cukup berpengaruh dan berdampak baik dari aspek pengetahuan, sikap atau keterampilan kelompok wanita tani terhadap materi penyuluhan yang disampaikan. Sedangakan nilai Efektivitas Perubahan Perilaku (EPP) sebesar 46,2\% dalam kategori cukup efektif berarti penyuluhan tentang metode marinasi pra pengolahan daging ayam yang dilakukan cukup berpengaruh terhadap perubahan perilaku kelompok wanita tani.

\section{B. Hasil Uji t (Paired t-test)}

Hasil data nilai rata-rata pra test dan post test yang telah didapat terlebih dahulu dilakukan uji normalitas sebelum di analisis menggunakan uji paired t-test. Penggunaan 
uji normalitas digunakan untuk mengetahui normal atau tidaknya distribusi data yang

hipotesis sampel berasal dari populasi diperoleh. Dalam uji ini akan menguji

berdistribusi normal.

Tabel 3. Nilai Signifikasi Hasil Uji Normalitas

\begin{tabular}{lccc}
\hline \multicolumn{1}{c}{ Variabel } & $\begin{array}{c}\text { Korgomolov- } \\
\text { Smirnov } \boldsymbol{Z}\end{array}$ & $\begin{array}{c}\text { Asymp.Sig } \\
\text { (2-tailed) }\end{array}$ & Keterangan \\
\hline Skor pra test/sebelum penyuluhan & 0,748 & 0,630 & Normal \\
Skor post test/sesudah penyuluhan & 0,687 & 0,733 & Normal \\
\hline
\end{tabular}

Berdasarkan tabel diatas nilai signifikasi yang diperoleh dari hasil pra test sebesar 0,630 dan nilai signifikasi dari hasil post test sebesar 0,733. Dari nilai signifikasi yang diperoleh dari masingmasing variabel $>0,05$. Karena nilai signifikasi yang diperoleh >0,05, maka dapat disimpulkan bahwa data berdistribusi normal. Hal ini sesuai dengan pendapat asumsi uji normalitas menggunakan One Sample Kolmogorov Smirnov adalah : 1) Sig >0,05 berarti data terdistribusi dengan normal, 2) Sig $<0,05$ berarti data tidak terdistribusi dengan normal. Bila data berdistribusi normal dilakukan analisis dengan uji beda untuk menguji hipotesis komparatif dan nilai signifikasi dengan rumus Paired t-test.

Anastasya (2013), yang menyatakan bahwa

Tabel 2. Hasil Uji Paired T-Test Pra Test dan Post Test

\begin{tabular}{lcccc}
\hline Variabel & N & Rerata & Sig. (2-tailed) & Keterangan \\
\hline Hasil pra test/sebelum penyuluhan & 34 & 37,6 & 0,000 & Signifikan \\
Hasil post test/sesudah penyuluhan & 34 & 57,2 & & \\
\hline
\end{tabular}

Berdasarkan tabel diatas dapat dilihat bahwa nilai signifikasi yang diperoleh lebih kecil dari 0,05 yaitu sebesar 0,000. Dengan demikian dapat disimpulkan bahwa hasil hipotesis sebelumnya melalui SPSS 16 diperoleh bahwa ada perubahan yang signifikan antara pra test dengan post test. Hal ini dapat dilihat dari hasil perolehan nilai t-test dan nilai sig.(2-tailed) yang berada dibawah 0,05. Hal ini berarti rumusan hipotesis yang menyatakan terdapat perbedaan yang nyata antara pra test (sebelum) dan post test (setelah) dilakukan penyuluhan terbukti. Nilai ratarata respon yang diperoleh sebelum penyuluhan sebesar 37,6, sedangkan nilai rata-rata respon yang diperoleh setelah penyuluhan sebesar 57,3. Memperhatikan hal ini, maka dapat ditarik kesimpulan bahwa respon wanita tani "Sidomaju" berbeda sangat nyata antara hasil pra test (sebelum) dilakukan penyuluhan dengan post test (sesudah) dilakukan penyuluhan.

\section{SIMPULAN DAN SARAN}

\section{A. Simpulan}

Hasil dari kegiatan Karya Ilmiah Penugasan Akhir (KIPA) di Kelompok Wanita Tani Sidomaju Desa Banjarsari Kecamatan Windusari Kabupaten Magelang Provinsi Jawa Tengah, dapat disimpulkan sebagai berikut :

1. Berdasarkan hasil kajian pelaksanaan penyuluhan dapat disimpulkan bahwa respon anggota kelompok wanita tani terhadap materi tentang metode marinasi pra pengolahan daging ayam dari hasil analisis secara keseluruhan 
menunjukkan bahwa respon dari aspek pengetahuan, aspek sikap dan aspek keterampilan diperoleh nilai pra test 37,6 (respon rendaah), sedangkan hasil rata-rata nilai post test menjadi 57,2 (respon tinggi).

2. Efektivitas Penyuluhan (EP) dari aspek pengetahuan, sikap dan keterampilan (perilaku) adalah sebesar $71,5 \%$ termasuk dalam kategori efektif. Sedangkan hasil dari Efektivitas Perubahan Perilaku (EPP) dari seluruh aspek adalah sebesar $46,2 \%$ termasuk dalam kategori cukup efektif.

3. Berdasarkan hasil analisis statistik menggunakan uji paired $t$-testterdapat perbedaan yang nyata/signifikan antara respon petani pada saat pra test (sebelum) dan post test (setelah) dilakukan penyuluhan dengan nilai signifikasi $<0,05$.

\section{B. Saran}

Berdasarkan hasil kegiatan Karya Ilmiah Penugasan Akhir (KIPA) yang telah dilaksanakan terdapat beberapa hal yang disankan diantaranya adalah :

1. Setelah dilakukan penyuluhan harus dilakukan pendekatan perorangan, sehingga respon petani meningkat seperti yang diharapkan.

2. Kegiatan penyuluhan sebaiknya dilakukan secara berkelanjutan dan dapat dilaksanakan oleh penyuluh setempat dan Balai Penyuluhan Pertanian.

\section{DAFTAR PUSTAKA}

Alvitri, W, Subejo, Harsoyo Lukman. 2015. Respons petani terhadap inovasi budidaya dan pemanfaatan sorgum di Kecamatan Srandakan Kabupaten Bantul.

Andi. 2012. Pengertian respon. Diakses 11 Februari

2018.https://pratamasandra.wordpre ss.com/2011/05/11/pengertianrespon/

Arikunto. 2000. Uji validitas kuisioner. Diakses $\quad 11 \quad$ Februari 2018.https://media-penyuluhanpertanian.blogspot.co.id/2013/12/.

Arikunto. 2010. Uji validitas kuisioner. Diakses $\quad 11 \quad$ Februari 2018.https://media-penyuluhanpertanian.blogspot.co.id/2013/12/.

Jajaka. 2013. Reliabilitas. Diakses 12 Februari 2018.http://jajakaaja.blogspot.co.id/2013/07/ujireliabilitas-dan-uji-validasi.html Matondang. 2009. Instrumen penyuluhan. Diakses $\quad 11 \quad$ Februari 2018.http://www.pengertianmenurut paraahli.net/pengertian-penyuluhanpertanian-menurut-para-ahli/

Notoatmojo. 2003. Sasaran penyuluhan pertanian. Diakses 05 desember 2017.http://thophick.blogspot.co.id/ 2009/05/peranan-penyuluhanpertanian-dalam.html?m1

Sasetyowati. 2013. Pengambilan sampel.

Diakses $\quad 12 \quad$ Februari

2018.https://id.123dok.com/docume nt/qv19redy-analisis-faktor-faktoryang-mempengaruhi-pendapatanpedagang-sembako-suatu-kasuspada-pedagang-sembako-di-pasarpananjung-kecamatanpangandaran.html

Sunaryo. 2004. Aspek sikap. Diakses 11 Februari

2018.http://cristianpradana.blogspot. co.id/2012/11/konsep-perilaku.html 